\title{
Sexual practices and its predictors among in-school adolescents in an urban city in North Central Nigeria
}

\author{
Aderibigbe S.A. ${ }^{1}$, Ayoola V. ${ }^{1}$, *Akande O.W. ${ }^{2}$, Fasiku M.M. ${ }^{1}$, Popoola G.O. ${ }^{1}$
}

\begin{abstract}
Objective: To assess the sexual practices and its predictors among in-school adolescents in Ilorin metropolis, Nigeria.
\end{abstract}

Methods: A descriptive cross-sectional study design was employed, using a pretested semi-structured interviewer administered questionnaire from 400 respondents via multistage sampling technique.

Results: Almost half of the respondents (47.5\%) have had only one sexual partner before and more than half of them $(52.5 \%)$ have had two or more partners. Less than one fifth of the respondents $(18.0 \%)$ had had sexual intercourse. More than half of the respondents (56.9\%) who were sexually active used condom at first experience. Respondents' age, gender and religion were important predictors of sexual behaviour.

Conclusion: Risky sexual practices are high in Nigeria and young people especially girls are at risk of morbidity and mortality due to sexually transmitted infections including HIV/AIDS, complications from unsafe abortion and social exclusion from stigmatization thereby calling for extra attention to this population.

Key words: Adolescents, sexual practices, risky sexual behaviour, sexually transmitted infections.

\author{
*Corresponding author \\ Akande O.W. \\ http://orcid.org/0000-0001-6906-895X \\ E-mail:akande.wuraola@gmail.com
}

Department of Epidemiology and Community Health, Faculty of Clinical Sciences, University of Ilorin, Ilorin, Nigeria.

${ }^{2}$ University of Ilorin Teaching Hospital, Ilorin, Nigeria.

\footnotetext{
Research Journal of Health Sciences subscribed to terms and conditions of Open Access publication. Articles are distributed under the terms of Creative Commons Licence (CC BY-NC-ND 4.0). (http://creativecommons.org/licences/by-nc-nd/4.0).

http://dx.doi.org/10.4314/rejhs.v7i4.4
} 


\title{
Pratiques sexuelles et leurs prédicateurs chez les adolescents ecoliers dans une ville du Nord du Nigéria
}

\author{
Aderibigbe S.A. ${ }^{,}$, Ayoola V. ${ }^{1},{ }^{*}$ Akande O.W. ${ }^{2}$, Fasiku M.M. ${ }^{1}$, Popoola G.O. ${ }^{1}$
}

\section{Résumé}

Objectif de l'étude: Évaluer les pratiques sexuelles et leurs prédicateurs chez les adolescents écoliers dans la métropole d'Ilorin au Nigéria.

Méthodes de l'étude: Une étude descriptive transversale a été adoptée, utilisant un questionnaire pré-test administré par un enquêteur semi-structuré à partir de 400 répondants via une technique d'échantillonnage en plusieurs techniques.

Résultats: Près de la moitié des répondants (47.5\%) n'avaient eu qu'un seul partenaire sexuel auparavant et plus de la moitié d'entre eux $(52.5 \%)$ avaient eu deux partenaires ou plus. Moins du cinquième des répondants $(18.0 \%)$ avaient eu des rapports sexuels. Plus de la moitié des répondants $(56.9 \%)$ sexuellement actifs ont utilisé un préservatif lors de leur première expérience. L'âge, le sexe et la religion des répondants étaient des prédicateurs importants du comportement sexuel.

Conclusion: Les pratiques sexuelles à risque sont nombreuses au Nigéria et les jeunes, en particulier les filles, sont menacées de morbidité et de mortalité à cause d'infections sexuellement transmissibles, notamment le VIH/SIDA, aux complications résultant d'un avortement non médicalisé et à l'exclusion sociale de la stigmatisation, appelant de ce fait une attention supplémentaire.

Mots-clés: Adolescents, pratiques sexuelles, comportements sexuels à risque, infections sexuellement transmissibles.

\footnotetext{
* Auteur Correspondant Akande O.W.

http://orcid.org/0000-0001-6906-895X

E-mail:akande.wuraola@gmail.com
}

Department of Epidemiology and Community Health, Faculty of Clinical Sciences, University of Ilorin, Ilorin, Nigeria.

${ }^{2}$ University of Ilorin Teaching Hospital, Ilorin, Nigeria. 


\section{INTRODUCTION}

Adolescent reproductive health can be defined as a state of complete physical, mental and social well-being and not only the absence of reproductive diseases or infirmities in all matters of the reproductive system, its functions and processes in persons between the ages of 10 to 19 years (1). The average adolescent is characterised by high energy levels, pursuit of adventure, dating, sexual experimentation, zealousness, radicalism, rebellion, curiosity and risky sexual behaviour; the outcome of which more often than not, compromises his/her sexual and reproductive health $(2,3)$. This group otherwise known as young people are an important segment of our Nigerian society where they make up about a third (31.6\%) of Nigeria's large and growing population (4). Not until recently, the Nigerian adolescent group were seen as a healthy segment of the populace who received low priority for health services, but biology and the society bring on additional health challenges to them; those stemming from unprotected sex, teenage pregnancies, transactional sexual relationships, multiple sexual partners, and trans-generational sexual relationships among others (4).

In order to wholly tackle the health and development needs of adolescents, it is pertinent to provide health services beyond the scope of adolescent pregnancy and HIV (5). Adolescents see themselves as mature enough to begin sexual activities but ironically, they do not have adequate knowledge on the repercussions of unprotected sex. Some of these repercussions include morbidity and mortality from sexually transmitted infections, unwanted pregnancy and complications of unsafe abortion. Adolescents develop self-consciousness in how other see them and most often, they do not disclose their reproductive health problems and in turn do not to use the appropriate health services they require (5). This may not be unrelated to poor information on reproductive health, inadequate financial resources and undesirable attitudes of health workers (5).

Reproductive health of adolescents is interdependent on several complex factors such as socio-cultural influences (from family, peers and communities), and access to health services, educational services and employment opportunities (5). While male and female adolescents have many reproductive health challenges, the female adolescents have more reproductive health needs that are gender specific (5). For instance, the female adolescent stands a risk of pregnancy, unsafe abortion complications, pregnancy-induced hypertension, obstructed labour, emotional traumas associated with unwanted pregnancy among others (6). The major objective of this study is to assess the sexual practices of adolescents attending schools in Ilorin metropolis, Kwara State, Nigeria.

\section{MATERIALS AND METHODS}

Description of the study area: Ilorin, the capital of Kwara State is located within the North Central geopolitical zone of Nigeria. The city is formed by most part of three local government areas namely: Ilorin East, Ilorin South and Ilorin West LGAs. There are 35 wards in the three local governments, of these, 22 of the wards form Ilorin metropolis (7). Higher institutions in Ilorin include the University of Ilorin, Kwara State Polytechnic, College of Education, School of Nursing and Midwifery, Ilorin. The culture in Ilorin is a mixture of Yoruba, Fulani and Hausa, which has been greatly influenced by Islamic culture (2).

Study design: The study was a descriptive crosssectional study among adolescents attending schools in Ilorin metropolis

Study population: The respondents of the survey were unmarried adolescents in secondary schools aged $10-19$ years.

Sample size: The sample size of 400 was estimated using Fischer's method of sample size determination to calculate the sample size using a $50 \%$ prevalence of sexual activity among in school adolescents (8). After calculation, the sample size was 384 , but the number was rounded up to 400 to increase the power of the study.

Sampling technique: Selection of the respondents consisted of a multi-staged sampling technique.

Stage 1: One (Ilorin East) out of the three LGAs was selected using simple random sampling via table of random numbers.

Stage 2: Three wards in the urban area of Ilorin East local government were selected using simple random sampling via table of random numbers.

Stage 3: A school was selected from each of the three wards using simple random technique via table of random numbers.

Stage 4: Students were selected from each of the three schools by systematic random sampling using a sampling interval. The sampling interval was calculated by dividing the estimated adolescent population size in the local 
government selected that are attending school by the sample size and a sampling frame of 8 was arrived at. Simple random sampling by balloting was used to select the first respondent and then the sampling frame was followed in a systematic manner until the desired sample size was completely selected.

Study Instruments/Tools: The data was collected using a pre-tested, semi-structured interviewer administered questionnaire. The questionnaire was developed by reviewing relevant literature on the subject to ensure reliability.

Data Management/ Statistical Analysis: Correctly completed questionnaires were sorted out. Information was coded and data was analysed using SPSS software version 21. Data collected were presented in prose, frequency tables, charts and graphs. A confidence limit of $95 \%$ was used and a $\mathrm{p}$ - value of $<0.05$ was considered significant.

Ethical Considerations: Ethical clearance was obtained from the Ethical Review Committee of University of Ilorin before the commencement of the study. A written informed consent was obtained from each participant 18 and above, while parental consent and assent were obtained for those less than 18 before recruitment into the study. Consenting participants were requested to append their signatures.

\section{RESULTS}

As reflected in Table 1, about three quarter of the respondents $(75.2 \%)$ were between the ages of $15-19$. The mean age of respondents was $15.65 \pm 1.73$. Sex distribution among respondents was almost equal, females accounted for $50.5 \%$ while males accounted for $49.5 \%$. Many of the respondents were Christians (57.3\%) and majority of the them were Yoruba (87.5\%). Most of the respondents' parents were educated (fathers, 93\%; mothers, 92.5\%) and also, most of them were employed (fathers, $94.8 \%$; mothers, $95.8 \%)$.

Questions assessing sexual practices among respondents revealed that $49.5 \%$ (198) had had a girl/boyfriend before (Table 2). Among those who have had a boy/girlfriend before, $47.5 \%$ (94) had had only one partner before, while $52.5 \%$ (104) had had two or more partners. Less than one third of the respondents $(20.8 \%)$ had been involved in sexual foreplay and majority of these respondents who had been involved in foreplay $(86.7 \%)$ had had sexual intercourse. Mean age of sexual debut was $12.96 \pm 2.33$ and $56.9 \%$ (41) of them who had had sexual intercourse reportedly used a condom at first experience. Less than half of the respondents, (47.2\%) had multiple sexual partners. Majority of respondents who were sexually active $(68.1 \%)$ posited to always use a form of contraception during or after sexual intercourse. Among those who said they use contraception, more than three quarter of them (77.6\%) stated that they use condoms, while the rest of them (22.4\%) reportedly used emergency contraceptive pills.

Among those who asserted that they were sexually active, $61.1 \%$ of them said their partners used contraception before during or after sexual intercourse (Table 3). Among those who said their partners used contraception, $75.0 \%$ (33) asserted their partners used condoms, 18.2\% (8) stated that their partners used emergency contraceptive pills, and 6.8\% (3) claimed their partners used oral contraceptives. Less than one fifth of them (17.7\%) posited that they had had sexual relations with a much older person and amongst them, $54.3 \%$ of the respondents said they used condoms while $45.7 \%$ (21) said they did not use condoms. Among those who did not use condoms, most of them (42.9\%) did not use condoms because they were forced into the sexual act, $38.1 \%$ of them said they preferred not to use condom, $9.5 \%$ said their partners did not like condoms and another $9.5 \%$ of them said they did not think it was necessary. A majority of the respondents $(73.6 \%)$ who were sexually active that had had sexual intercourse with someone of the same sex. Out of the sexually active respondents, about a quarter of them (26.4\%) of them had been infected with a sexually transmitted disease in the past. Less than half of the sexually active respondents $(38.9 \%)$ claimed to had been pregnant or had impregnated someone before; amongst these respondents, half of them $(50 \%)$ said the baby was delivered, $35.7 \%$ said the pregnancy was aborted, and $14.3 \%$ said it was miscarried.

Cross tabulation found a statistically significant association between some sociodemographic variables of the respondents (age, gender and religion) and their sexual behaviour (Table 4). Most of the respondents who posited to have had at least one sexual intercourse experience $61(84.7 \%)$ were between the ages of 15-19 revealing that the older adolescents were more sexually active than the younger ones between the ages of $10-14$. Also, among the 
respondents that were sexually active, majority of them $(69.4 \%)$ were male respondents and more than half of the sexually active respondents 39 $(54.2 \%)$ practiced Islam. The level of education and employment status of respondents' fathers were also shown to have an association with their sexual behaviour. Among those who were sexually active, $88.9 \%$ of their fathers were employed, and $86.1 \%$ of their fathers were educated.

Gender, religion and father's level of education were found to be the only statistically significant predictors of sexual activity (Table 5). Male gender and the uneducated level of education of fathers were found to be positive predictors while Christian religion was found to be a negative predictor. Male respondents were found to be 2.362 times more likely to be sexually active than their female peers, that is a $70.6 \%$ chance that sexually active respondents were males. Christian respondents were found to be about 0.6 times less likely to be sexually active compared to the respondents who practised Islam. Also, respondents whose fathers were uneducated were about 3 times more likely to be sexually active.

\section{DISCUSSION}

This study assessed the sexual practices of adolescents attending schools in Ilorin metropolis. It specifically focused on assessing the sexual practices adolescents in school are involved in. All respondents were between the ages of 10 to 19 with mean age of 15.65 as was found with other studies (9-11).

Questions assessing their use of contraceptives revealed that of all the respondents who were sexually active, only about $56.9 \%$ of them used a condom at first sexual intercourse. When asked if they used contraceptives during or after sexual intercourse, $68.1 \%$ of the respondents said they did. These findings were found to be consistent with findings from other studies conducted in the north east and north central parts of Nigeria and also in Brazil (12-14). Of all the types of contraceptives, condoms $(77.6 \%)$ and emergency contraceptives $(22.4 \%)$ were the most commonly used contraceptives among the sexually active respondents. This is consistent with another study (15). The mean age of sexual debut was $12.96 \pm$ 2.33 standard deviation, this in line with other studies goes further to prove that the age of sexual debut is drastically dropping (16-18). Most of the adolescents do not usually have a choice as to when to begin sexual exploration due to lack of adequate information of the risks involved in early sexual debut, pressures from peers, societal and economic factors. Findings from this study showed that $47.2 \%$ of the respondents had two or more sexual partners. This finding correlates with results from other studies carried out in subSaharan Africa (19-22). More males (69.4\%) than females $(30.6 \%)$ had multiple sexual partners which is also in line with other studies $(22,23)$. About a quarter $(26.4 \%)$ of sexually active respondents had experienced a form of sexually transmitted infection. Studies conducted by the WHO have shown that a large proportion of infections are believed to occur in young people less than 25 years, majority of these infections occur among those within the with the 20-24 year age group followed by those within the 15-19 year age group (24). Evidence has shown a wide range of prevalence of STIs among adolescents. These is higher than the $10-20 \%$ prevalence found among sexually-active girls in rural areas of Uganda and Nigeria, but lower than the greater than $40 \%$ prevalence found among adolescent sex workers in Senegal and a sample of high-risk pregnant girls in Brazil(24).

About two thirds of the sexually active respondents $(63.9 \%)$ claimed to have had sexual relations with a much older partner, of these respondents, $45.7 \%$ of them did not use a condom. When asked the reason they didn't use condom, some of them $42.9 \%$ said they were forced and some $38.1 \%$ said they preferred not to. These findings are congruent with other studies which have shown that engaging in sexual relations with older partners is not uncommon among adolescent girls in Africa. The majority of adolescent girls' partners are usually several years older and a lesser proportion of them have partners of similar ages or younger. (25) Evidence has also shown a possible trend: the older the adolescent girl, the more likely they are to be involved in sexual activities with older partners (25). When asked if they have ever been pregnant or have impregnated a girl before, $38.9 \%$ of the sexually active respondents acclaimed to this. When asked about the outcome of the pregnancy, $50 \%$ delivered the baby, $35.7 \%$ aborted the pregnancy and $14.3 \%$ ended in a miscarriage. These findings support other studies which indicates a high rate of abortion among the adolescent age group $(6,14,26)$. Pregnancy among unmarried adolescents is of public health concern especially in developing countries. Over 14 million adolescent girls give birth annually (27). In Nigeria, about a million adolescent girls get pregnant and majority of these pregnancies 
are unplanned (27). Unintended adolescent pregnancies come with negative health and social consequences, some of which include: increased risk of maternal death, termination of education, job loss, discrimination and stigmatisation $(27,28)$.

Analysis of the factors influencing sexual practices among the respondents revealed that respondents' age, gender and religion are important factors that affect their sexual practice. Majority of the respondents who posited to have had at least one sexual intercourse experience $(84.7 \%)$ were between the ages of $15-19$ revealing that the older adolescents were more sexually active than the younger ones between the ages of $10-14$. This is in line with other studies carried out in sub Saharan Africa $(29,30)$. Also, among the respondents who were reportedly sexually active, majority of them $(69.4 \%)$ were male respondents and more than half of them (54.2\%) practiced Islam. Furthermore, the respondents' father's level of education and employment status had statistical significance on their sexual practices, this is finding is similar to that found in another study carried out in Benin, Nigeria (31).

This study found male gender, having uneducated fathers and having unemployed fathers to be positive predictors of being sexually active while being a Christian was found to be a negative predictor. These findings correlate with findings from other studies which revealed that male gender and low socio-economic status are associated with a higher probability of being sexually active and thus engaging in risky sexual behaviour (32). Other studies stated that while many factors such as poor negotiating skills, low self-esteem, gender norms and peer pressure have been identified to influence the sexual behaviour of adolescents in Nigeria, the influencing factors differ according to the context in which adolescents in Nigeria live (33). They stated that many factors act as drivers to adolescent sexual initiation and reasons for sexual behaviour. Among the top reasons given by adolescents who participated in a national survey across 12 states in Nigeria for their sexual activity were; the show of love, to derive pleasure, to have fun and to satisfy curiosity. Others on the other hand said they were forced into sex, or had sex for the financial and material gain (33).

The aim of this study was to assess the sexual practices indulged in by adolescents attending schools in Ilorin metropolis. This study revealed that there is an increasing need to pay more attention to the reproductive health needs of this population as a significant proportion of them are sexually active and there is evidence to show that the age at sexual debut is decreasing. This study also suggests that substantial percentage of female adolescents are having unwanted pregnancies and are at risk of unsafe abortion. As the incidence and prevalence of unwanted pregnancies and abortions are high in Nigeria, Sub-Sahara Africa and even in the western world, more and more young people especially girls are at risk of morbidity and mortality due to sexually transmitted infections including HIV/AIDS, complications from unsafe abortion and social exclusion from stigmatization. This study also points out the prevalence of same sex sexual activity among adolescents. Sexual education should be taught to these adolescents in schools and youth friendly services made accessible to them. Sexual activity among adolescents is influenced by multiple factors including age, gender and religion of adolescents and the educational and employment status of their parents especially their fathers. It is important to take into cognizance these factors when providing interventions to address the sexual health challenges of adolescents in order to prevent negative sexual and reproductive health outcomes such as STI, unintended pregnancy and unsafe abortion.

Conflicts of interest: The authors declares no conflicts of interest.

\section{REFERENCES}

1. Department of Reproductive Health and Research, World Health Organisation. The sexual and reproductive health of younger adolescents [Internet]. Geneva, Switzerland: World Health Organisation 2011 [cited 2016 March 10]. A v a i 1 a b l e f $\mathrm{r}$ o m : www.who.int/reproductivehealth/publications/ad olescence/rhr_11_15/en/.

2. Oke K. Sexual Behaviour of Adolescent Hawkers in Ilorin Metropolis: The role of Sociodemographic predictors. BJA Educ. 2016;4(8):23 -35 .

3. Ofole NM, Agokei SP. Risky sexual behaviours among female in-school adolescents in Delta, Nigeria: self-esteem, parental involvement and religiosity as predictors. ESJ. 2014;10(31):157 77.

4. Ndyanabangi B, Kipp W, Diesfeld H. Reproductive Health Behaviour among In-School and Out-of-School Youth in Kabarole District, Uganda. Afr J Reprod Health

1. 2004;8(3):55-67.

5. Atuyambe LM, Kibira PS, Bukenya J, Muhumuza C, Apolot RR, Mulogo E. Understanding sexual 
and reproductive health needs of adolescents evidence from a formative evaluation in Wakiso district, Uganda. Reproductive Health. 2015; 12(35).

6. Aderibigbe SA, Araoye MO, Akande TM, Musa OI, Monehin JO, Babatunde OA. Teenage Pregnancy and Prevalence of Abortion among Inschool Adolescents in North Central, Nigeria. Asian Social Science. 2011;7(1):122 -7.

7. Babatunde OA, Ibirongbe DO, Omede $\mathrm{O}$, Babatunde OO, Durowade KA, Salaudeen AG, et al. Knowledge and use of emergency contraception among students of public secondary schools in Ilorin, Nigeria. Pan Afr Med J. 2016;23(74).

8. Orji EO and Esimai OA. Sex behaviour and contraceptive use among secondary school students in Ilesha South West Nigeria uality and contraception among Nigerian adolescents and youth. Journal of Obstetrics and Gynaecology 2005; 25(3): 269-72

9. Cortez R, Saadat S, Marinda E, Oluwole O. Adolescent sexual and reproductive health in Nigeria. . Washington, DC. World Bank Group, 2015.

10. Okonofua F. New Research Findings on Adolescent Reproductive Health in Africa. Afr J Reprod Health. 2007;11(3):7-9.

11. Nnorom CP, Bammeke F. Extent Of Adolescents' Knowledge Of Sexual And Reproductive Health And Rights In Nigeria: Implications For Development [Internet]. Lagos: University of Lagos; 2012 [cited 2016 March 10]. Available f $\begin{array}{llll}r & 0 & m\end{array}$ https://epc2008.princeton.edu/papers/80707

12. Amazigo U, Silva N, Kaufman J, Obikeze DS. Sexual activity and contraceptive knowledge and use among In-school Adolescents in Nigeria. International Family Planning Perspectives. 1997;23(1):28-33

13. Chimah UC, Lawoyin TO, Ilika AL, Nnebue CC. Contraceptive knowledge and practice among senior secondary schools students in military barracks in Nigeria. Niger J Clin Pract. 2016;19(2):182-8.

14. Almeida Maria da Conceição Chagas de, Aquino Estela Maria Leão de, Gaffikin Lynne, Magnani Robert J. Uso de contracepção por adolescentes de escolas públicas na Bahia. Rev. Saúde Pública [Internet]. 2003 Oct [cited 2016 July 11];37( 5 ): $566-575$. A v a i 1 a b 1 e from: http://www.scielo.br/scielo.php?script=sci artte $\mathrm{xt} \& \mathrm{pid}=\mathrm{S} 0034-89102003000500004 \& \ln \overline{\mathrm{g}}=\mathrm{en}$. http://dx.doi.org/10.1590/S003489102003000500004

15. Okpani AOU, Okpani JU. Sexual Activity and Contraceptive Use among Female Adolescents - A report from Port Harcourt, Nigeria. Afr J Reprod Health. 2000;4(1):40-7.

16. Nnebue CC, Chimah UC, Duru CB, Ilika AL, Lawoyin TO. Determinants of Age at Sexual Initiation among Nigerian Adolescents: A Study of Secondary Schools Students in a Military Barracks in Nigeria. Am J Med Sci. 2016;4(1):17.

17. Ajibade BL, Oyedele EA, Ajayi AD. Adolescents Health and Management of Sexual Risk Taking Behaviour among Selected Secondary School Students in Osun State, Nigeria. European Journal of Business and Management. 2013;5(29):15-25.

18. Bukar M, Audu BM, Kawuwa MB, Ibrahim SM, Ali F. Determinants of premarital sex in Maiduguri, Nigeria: Implications for Human Papilloma Virus vaccination. Int J Res Med Sci. 2013;2(3):195-201.

19. Santelli JS, Brener ND, Lowry R, Bhatt A, Zabin LS. Multiple Sexual Partners Among U.S. Adolescents And Young Adults. Fam Plann Perspect. 1998;30(6):271-5.

20. Exavery A, Lutambi AM, Mubyazi GM, Kweka K, Mbaruku G, Masanja H. Multiple sexual partners and condom use among 10 - 19 year-olds in four districts in Tanzania: What do we learn? BMC Public Health. 2011;11(490):1-9.

21. Pilgrim NA, Ahmed S, Gray RH, Sekasanvu J, Lutalo T, Nalugoda F, et al. Multiple Sexual Partnerships among Female Adolescents in Rural Uganda: The effects of family structure and school attendance. Int $\mathrm{J}$ Adolesc Med Health. 2015;27(3):319-28.

22. Hindin MJ, Fatusi AO. Adolescent Sexual and Reproductive Health inDeveloping Countries:AnOverview of Trends and Interventions. Int Perspect Sex Reprod Health. 2009;35(2):58-62.

23. Olugbenga-Bello AI, Adebimpe WO, Abodunrin OL. Sexual Risk Behaviour Among In-School Adolescents in Public Secondary Schools in a Southwestern City in Nigeria. International Journal of Health Research. 2009;2(3):243 - 51.

24. Dehne KL, Riedner G. Sexually Transmitted Infections Among Adolescents: The Need for Adequate Health Services. Marketing and Dissemination, World Health Organization, 20 Avenue Appia, 1211 Geneva 27, Switzerland: World Health Organization and Deutsche Gesellschaft fuer Technische Zusammenarbeit, 2005.

25. Luke N, Kurz KM. Cross-generational and Transactional Sexual Relations in Sub-Saharan Africa: Prevalence of Behavior and Implications for Negotiating Safer Sexual Practices [Internet]. United States: International Center for Research on Women; 2002. [cited 2016 March 10]. Available from: https://www.icrw.org/wpcontent/uploads/2016/10/Cross-generationaland-Transactional-Sexual-Relations-in-SubSaharan-Africa-Prevalence-of-Behavior-andImplications-for-Negotiating-Safer-SexualPractices.pdf

26. Lamina MA. Prevalence and determinants of unintended pregancy among women in southwestern Nigeria. Ghana Med J. 2015;49(3):18794. 
27. Ilika A, Anthony I. Unintended Pregnancy among Unmarried Adolescents and Young Women in Anambra State, South East Nigeria. Afr J Reprod Health. 2004;8(3):92-102.

28. Olaitan LO. Perception of university students on unwanted pregnancy in south west Nigeria American Journal of Social and Management Sciences. 2010;1(2):196-200

29. Darteh KM, Kumi-Kyereme A, Awusabo-Asare K. Perception of Risk of HIV among Adolescents' Living in an Urban Slum in Ghana. Afr J Reprod Health. 2016;20(1):62-70.

30. Maswanya ES, Moji K, Horiguchi I, Nagata K, Aoyagi K, Honda S, et al. Knowledge, risk perception of AIDS and reported sexual behaviour among students in secondary schools and colleges in Tanzania. Health Educ Res.
1999;14(2):185-96.

31. Teanin MJ, Okonofua FE, Omorodion FO, Renne EP, Coplan P, Heggenhougen HK, et al. Perceptions of sexual behavior and knowledge about sexually transmitted diseases among adolescents in Benin City, Nigeria. Int Fam Plan Perspect. 1999;25(4):186-95.

32. Kabiru CW, Orpinas P. Factors associated with sexual activity among high-school students in Nairobi, Kenya. J Adolesc. 2009 : Aug;32(4):1023-39

33. Envuladu EA, Kwaak AV, Zwanikken P, Zoakah AI. Exploring the Factors Influencing Adolescent Sexual Behavior in Plateau State Nigeria. American Journal of Medicine and Medical Sciences. 2017;7(1):1-6. 
Table 1: Distribution of Respondents according to socio-demographic characteristics

\begin{tabular}{|c|c|c|}
\hline & Frequency & Percent \\
\hline Socio-demographic variables & $\mathbf{n}$ & $(\%)$ \\
\hline \multicolumn{3}{|l|}{ Age group (years) } \\
\hline $10-14$ & 99 & 24.8 \\
\hline $15-19$ & 301 & 75.2 \\
\hline Mean $\pm S D$ (years) & \multicolumn{2}{|c|}{$15.65 \pm 1.73$} \\
\hline \multicolumn{3}{|l|}{ Sex } \\
\hline Male & 198 & 49.5 \\
\hline Female & 202 & 50.5 \\
\hline \multicolumn{3}{|l|}{ Religion } \\
\hline Christianity & 229 & 57.3 \\
\hline Islam & 171 & 42.7 \\
\hline \multicolumn{3}{|l|}{ Ethnicity } \\
\hline Yoruba & 350 & 87.5 \\
\hline Igbo & 13 & 3.3 \\
\hline Hausa & 6 & 1.5 \\
\hline Others & 31 & 7.7 \\
\hline \multicolumn{3}{|l|}{ Mother's employment status } \\
\hline Unemployed & 17 & 4.2 \\
\hline Employed & 383 & 95.8 \\
\hline \multicolumn{3}{|l|}{ Father's employment status } \\
\hline Unemployed & 21 & 5.2 \\
\hline Employed & 379 & 94.8 \\
\hline \multicolumn{3}{|l|}{ Mother's educational status } \\
\hline Uneducated & 30 & 7.5 \\
\hline Educated & 370 & 92.5 \\
\hline \multicolumn{3}{|l|}{ Father's educational status } \\
\hline Uneducated & 28 & 7.0 \\
\hline Educated & 372 & 93.0 \\
\hline \multicolumn{3}{|l|}{ Mother's occupation } \\
\hline Unemployed & 17 & 4.3 \\
\hline Professional & 61 & 15.2 \\
\hline Civil servant & 142 & 35.5 \\
\hline Business & 161 & 40.2 \\
\hline Artisan & 11 & 2.8 \\
\hline Armed forces & 8 & 2.0 \\
\hline \multicolumn{3}{|l|}{ Father's occupation } \\
\hline Unemployed & 21 & 5.2 \\
\hline Professional & 76 & 19.0 \\
\hline Civil servant & 148 & 37.0 \\
\hline Business & 121 & 30.3 \\
\hline Artisan & 16 & 4.0 \\
\hline No response & 18 & 4.5 \\
\hline
\end{tabular}


Table 2: Sexual Practices of Respondents

\begin{tabular}{|c|c|c|}
\hline Variable & $\begin{array}{l}\text { Frequency } \\
\text { n }\end{array}$ & $\begin{array}{l}\text { Percent } \\
(\%)\end{array}$ \\
\hline \multicolumn{3}{|l|}{ Ever had a girl/ boyfriend } \\
\hline Yes & 198 & 49.5 \\
\hline No & 202 & 50.5 \\
\hline \multicolumn{3}{|c|}{ If yes how many have you had $(n=198)$} \\
\hline 1 & 94 & 47.5 \\
\hline$=2$ & 104 & 52.5 \\
\hline \multicolumn{3}{|c|}{ Ever been involved in any sexual foreplay } \\
\hline Yes & 83 & 20.8 \\
\hline No & 317 & 79.2 \\
\hline \multicolumn{3}{|c|}{ Ever had sexual intercourse $(n=83)$} \\
\hline Yes & 72 & 86.7 \\
\hline No & 11 & 13.3 \\
\hline \multicolumn{3}{|l|}{ Age at first sexual intercourse } \\
\hline Mean \pm SD & $12.96 \pm 2.33$ & \\
\hline \multicolumn{3}{|c|}{$\begin{array}{l}\text { Use of condom at first sexual intercourse } \\
(n=72)\end{array}$} \\
\hline Yes & 41 & 56.9 \\
\hline No & 31 & 43.1 \\
\hline \multicolumn{3}{|l|}{ Multiple sexual partner $(n=72)$} \\
\hline Yes & 34 & 47.2 \\
\hline No & 38 & 52.8 \\
\hline \multicolumn{3}{|c|}{$\begin{array}{l}\text { Use of any form of contraception during or } \\
\text { after intercourse }(n=72)\end{array}$} \\
\hline Yes & 49 & 68.1 \\
\hline No & 23 & 31.9 \\
\hline \multicolumn{3}{|l|}{ Contraception used $(n=49)$} \\
\hline Condom & 38 & 77.6 \\
\hline Emergency contraceptive pills & 11 & 22.4 \\
\hline
\end{tabular}


Table 3: Sexual Practices of Respondents

\begin{tabular}{|c|c|c|}
\hline Variable & $\begin{array}{l}\text { Frequency } \\
\text { n }\end{array}$ & $\begin{array}{l}\text { Percent } \\
(\%)\end{array}$ \\
\hline \multicolumn{3}{|c|}{$\begin{array}{l}\text { Partner's use any form of contraception before } \\
\text { during or after sexual intercourse }(n=72)\end{array}$} \\
\hline Yes & 44 & 61.1 \\
\hline No & 28 & 38.9 \\
\hline \multicolumn{3}{|c|}{ Contraceptive used by partner $(n=44)$} \\
\hline Condom & 33 & 75.0 \\
\hline Emergency contraceptive pills & 8 & 18.2 \\
\hline Oral contraceptives & 3 & 6.8 \\
\hline Injectables & 0 & 0.0 \\
\hline \multicolumn{3}{|c|}{$\begin{array}{l}\text { Ever had sexual relations with a much older } \\
\text { person }(n=72)\end{array}$} \\
\hline Yes & 46 & 63.9 \\
\hline No & 26 & 36.1 \\
\hline \multicolumn{3}{|c|}{ If yes, did you use condom? $(n=46)$} \\
\hline Yes & 25 & 54.3 \\
\hline No & 21 & 45.7 \\
\hline \multicolumn{3}{|c|}{ Reasons for not using condom $(n=21)$} \\
\hline I was forced & 9 & 42.9 \\
\hline I prefer not to & 8 & 38.1 \\
\hline Partner doesn't like it & 2 & 9.5 \\
\hline I didn't think it was necessary & 2 & 9.5 \\
\hline \multicolumn{3}{|c|}{$\begin{array}{l}\text { Ever had sexual intercourse with someone of the } \\
\text { same sex as you }(n=72)\end{array}$} \\
\hline Yes & 53 & 73.6 \\
\hline No & 19 & 26.4 \\
\hline \multicolumn{3}{|c|}{ Experienced sexually transmitted disease $(n=72)$} \\
\hline Yes & 19 & 26.4 \\
\hline No & 53 & 73.6 \\
\hline \multicolumn{3}{|c|}{$\begin{array}{l}\text { Ever been pregnant/have ever impregnated a girl } \\
(n=72)\end{array}$} \\
\hline Yes & 28 & 38.9 \\
\hline No & 44 & 61.1 \\
\hline \multicolumn{3}{|l|}{ Outcome of the pregnancy $(n=28)$} \\
\hline Delivered the baby & 14 & 50.0 \\
\hline Aborted the pregnancy & 10 & 35.7 \\
\hline Miscarriage & 4 & 14.3 \\
\hline
\end{tabular}


Table 4: Association between Socio-demographic Characteristics of Respondents and Sexual Practices

\begin{tabular}{|c|c|c|c|c|}
\hline \multirow[b]{2}{*}{ Variable } & \multicolumn{3}{|c|}{ Sexual Intercourse } & \multirow[b]{2}{*}{$p$ value } \\
\hline & Yes & No & $\chi^{2}$ & \\
\hline & n (\%) & n (\%) & & \\
\hline \multicolumn{5}{|c|}{ Age group (years) } \\
\hline $10-14$ & $11(15.3)$ & $88(26.8)$ & 4.230 & $0.040 *$ \\
\hline $15-19$ & $61(84.7)$ & $240(73.2)$ & & \\
\hline \multicolumn{5}{|l|}{ Gender } \\
\hline Male & $50(69.4)$ & $148(45.1)$ & 13.972 & $<0.001 *$ \\
\hline Female & $22(30.6)$ & $180(54.9)$ & & \\
\hline \multicolumn{5}{|l|}{ Ethnicity } \\
\hline Yoruba & $59(81.9)$ & $291(88.7)$ & 3.854 & $0.278^{y}$ \\
\hline Igbo & $5(6.9)$ & $8(2.4)$ & & \\
\hline Hausa & $0(0.0)$ & $6(1.8)$ & & \\
\hline Others & $8(11.2)$ & $23(7.1)$ & & \\
\hline \multicolumn{5}{|l|}{ Religion } \\
\hline Christianity & $33(45.8)$ & $196(59.8)$ & 4.676 & $0.031 *$ \\
\hline Islam & $39(54.2)$ & $132(40.2)$ & & \\
\hline \multicolumn{5}{|c|}{$\begin{array}{l}\text { Mother's } \\
\text { employment status }\end{array}$} \\
\hline Unemployed & $4(5.6)$ & $13(4.0)$ & 0.368 & 0.544 \\
\hline Employed & $68(94.4)$ & $315(96.0)$ & & \\
\hline \multicolumn{5}{|c|}{$\begin{array}{l}\text { Father's employment } \\
\text { status }\end{array}$} \\
\hline Unemployed & $8(11.1)$ & $13(4.0)$ & 6.064 & $0.014 *$ \\
\hline Employed & $64(88.9)$ & $315(96.0)$ & & \\
\hline \multicolumn{5}{|c|}{$\begin{array}{l}\text { Mother's level of } \\
\text { education }\end{array}$} \\
\hline Uneducated & $5(6.9)$ & $25(7.6)$ & 0.039 & 0.843 \\
\hline Educated & $67(93.1)$ & $303(92.4)$ & & \\
\hline \multicolumn{5}{|c|}{$\begin{array}{l}\text { Father's level of } \\
\text { education }\end{array}$} \\
\hline Uneducated & $10(13.9)$ & $18(5.5)$ & 6.401 & $<0.011 *$ \\
\hline Educated & $62(86.1)$ & $310(94.5)$ & & \\
\hline
\end{tabular}

$\chi 2$ : chi square test, $y:$ yates $p$ value, ${ }^{*}: p$ value $<0.05$ (statistically significant)

Table 5: Predictors of sexual practices among respondents

\begin{tabular}{|c|c|c|c|c|c|}
\hline \multirow[t]{2}{*}{ Variable } & \multirow[t]{2}{*}{$\mathbf{B}$} & \multirow[t]{2}{*}{$p$ value } & \multirow[t]{2}{*}{ Odds Ratio } & \multicolumn{2}{|c|}{ 95\% Confidence Interval } \\
\hline & & & & Lower & Upper \\
\hline \multicolumn{6}{|l|}{ Age Group } \\
\hline $10-14$ & -0.545 & 0.158 & 0.580 & 0.271 & 1.244 \\
\hline \multicolumn{6}{|l|}{ Gender } \\
\hline Male & 0.860 & $0.005 *$ & 2.362 & 1.295 & 4.310 \\
\hline \multicolumn{6}{|l|}{ Religion } \\
\hline Christianity & -0.600 & $0.046 *$ & 0.549 & 0.304 & 0.989 \\
\hline \multicolumn{6}{|l|}{$\begin{array}{l}\text { Father's Level } \\
\text { of Education }\end{array}$} \\
\hline Uneducated & 1.173 & $0.004 *$ & 3.233 & 1.447 & 7.222 \\
\hline
\end{tabular}

B: coefficient of logistic regression; ${ }^{*}: p$ value $<0.05$ (statistically significant) 